\title{
Sedimentology and sediment geochemistry of the pelagic Paryab section (Zagros Mountains, Iran): implications for sea level fluctuations and paleoenvironments in the late Paleocene to middle Eocene
}

\author{
Seyed Hamidreza Azami ${ }^{1}$ (D) Michael Wagreich ${ }^{1}$ - Maryam Mortazavi Mehrizi ${ }^{2}$. \\ Mohamad Hosein Mahmudy Gharaie ${ }^{3}$. Susanne Gier ${ }^{1} \cdot$ R. Mark Leckie ${ }^{4}$
}

Received: 28 July 2020 / Accepted: 7 May 2021 / Published online: 30 May 2021

(C) The Author(s) 2021

\begin{abstract}
Sedimentological and geochemical records are presented for an upper Paleocene to middle Eocene deep-water pelagic succession of the Pabdeh Formation in the Paryab section, Zagros Mountains, NW, Iran. In this study, grain-size statistical parameters, cumulative curves, and bivariate analysis on twenty-five sediment samples were used to decipher depositional processes and paleoenvironments. XRD analysis of the fine-grained silt to clay sediments indicates that quartz, calcite, ankerite/dolomite, and clay minerals such as illite, chlorite, and kaolinite constitute the main minerals within these sediments. Elemental and isotopic chemostratigraphies are used to infer depositional conditions and sea level trends through time. $\mathrm{TOC}-\mathrm{CaCO}_{3}$ trends of the samples are used to interpret the type of deposition and sediment accumulation rates, rhythmic bedding, and identification of regressional and transgressional phases. In the studied section, the manganese contents exhibit a declining trend along the lowstand systems tract that terminates in a sea level lowstand and the subsequent start of a transgressive trend. Some geochemical parameters such as $\mathrm{Mn}$ values and $\delta^{13} \mathrm{C}$ contents of sediments along a sequence can be used as potential sea level proxies that are tested in this study. The Paleocene-Eocene Thermal Maximum (PETM) interval of the Pabdeh Formation coincides with increasing $\mathrm{Mn}$ contents and $\mathrm{Mn} / \mathrm{Al}$ ratios. Ti/Al and $\mathrm{Si} / \mathrm{Al}$ ratios show contrasting trends to $\mathrm{Mn}$ values and $\mathrm{Mn} / \mathrm{Al}$ ratios. Generally, elemental and isotopic results of the Pabdeh Formation confirm the presence of a long-term three-stage sea level cycle in the studied interval that is related to the PETM event. Based on elemental analyses such as $\mathrm{Co}, \mathrm{Mo}, \mathrm{Ni}, \mathrm{V}$, and $\mathrm{Cr}$ contents, the Pabdeh Formation sediments were deposited in suboxic to slightly anoxic conditions.
\end{abstract}

Keywords Sedimentology $\cdot$ Elemental and isotopic analyses $\cdot$ Sea level change $\cdot$ Pabdeh Formation $\cdot$ Zagros fold-thrust belt

Responsible Editor: Attila Ciner

Seyed Hamidreza Azami

seyed.hamidreza.azami@univie.ac.at

1 Department of Geodynamics and Sedimentology, University of Vienna, 1090 Vienna, Austria

2 Department of Geology, University of Birjand, Birjand, Iran

3 Department of Geology, Ferdowsi University of Mashhad, Mashhad, Iran

4 Department of Geosciences, University of Massachusetts Amherst, Amherst, MA 01003, USA

\section{Introduction}

The early Paleogene was characterized by a climatically dynamic cooling greenhouse period (e.g., Kidder and Worsley 2010) with a relatively sudden global warming event known as the Paleocene-Eocene Thermal Maximum (PETM; Kennett and Stott 1991; Thomas and Shackleton 1996; Zachos et al. 2008), characterized by a worldwide $5-8{ }^{\circ} \mathrm{C}$ warming of Earth's surface, as well as of the deep oceans (McInerney and Wing 2011; Dunkley Jones et al. 2013). The transition to this event has been estimated to have occurred within a few thousand years, the source and trigger of which still remain unresolved, although several hypotheses are currently being debated (e.g., Dickens et al. 1997; Kent et al. 2003; Svensen 
et al. 2004; Higgins and Schrag 2006; DeConto et al. 2012; Hönisch et al. 2012; Dunkley Jones et al. 2013). Numerous research results suggest a link between the global sea level rise and hyperthermal events such as the PETM (Haq et al. 1987; Sluijs et al. 2008; Kominz et al. 2008; Haq 2014).

Therefore, the use of sedimentological and geochemical analysis for reconstruction of sedimentary environmental conditions and sea level changes before, during, and after the PETM is the most important goal of this research. Environmental conditions and sedimentary facies can be driven by sea level fluctuations and geochemistry (e.g., Olde et al. 2015). Geochemical, lithological, and sedimentological data provide useful tools for the reconstruction of sea level fluctuations in the deeper-water pelagic sedimentary archive (Jarvis et al. 2001; Olde et al. 2015; Wagreich and Koukal 2019). Moreover, grain size constitutes one of the important and classical descriptive aspects of sediments and sedimentary rocks that is widely used to determine hydrodynamic conditions and depositional processes and to interpret depositional environments (Boggs 2009; Baiyegunhi et al. 2017).

In this study, three main aspects of particle size were utilized. In addition, geochemical analyses of the studied Paleocene-Eocene pelagic clastic and carbonate succession, including elemental and isotopic data, were carried out in order to perform environmental reconstructions in a robust stratigraphic framework of the studied section.

\section{Geological setting}

The studied strata at the Paryab section (N 33 $3^{\circ} 5^{\prime} 14^{\prime \prime}$, E $46^{\circ} 37^{\prime} 3.2^{\prime \prime}$ ) (Fig. 1) in the Zagros basin includes finegrained pelagic sediments from the uppermost middle to the upper Paleocene (Selandian-Thanetian, nannofossil zones CNP8 and NP6, respectively) to the middle Eocene (Lutetian, nannofossil zones CNE8 and NP14), an interval of around 10 to $11 \mathrm{myr}$ as reconstructed using cyclostratigraphy by Azami et al. (2018). In the study area, the gray shales of the Gurpi Formation are overlain by the basal purple shale unit of the Pabdeh Formation (Fig. 2). Above this reddish to gray shaly lower part, a prominent interval of limestone-marl cycles of the upper part of the Pabdeh Formation follows and is succeeded by the overlying limestones of the Asmari Formation of mainly Lutetian age. Lithology, cyclostratigraphy, and calcareous nannofossil biostratigraphy have already been studied for the Paryab section by Azami et al. (2018), including a high-resolution study for the PETM interval (Azami et al. 2018).

\section{Material and methods}

\section{Sedimentology}

Grain size distribution is widely used to interpret depositional processes, hydrodynamic conditions, and the depositional environment (Boggs 2009; Baiyegunhi et al. 2017). The grain size classes were determined using the Udden-Wentworth grade scale (Udden 1914; Wentworth 1922); and sand, silt, and clay weight percentages were calculated for all samples. Grain size analysis of deep marine sediments with paleoceanographic proxies has been used to document past changes in sea level and intensity of bottom currents and upwelling (Aiello and Kellett 2006; Wagreich and Koukal 2019). Twenty-five sediment samples were selected for detailed grain size analysis.

These samples were analyzed for their grain size distribution, grain size parameters, and statistical relationships using $\mathrm{X}$-ray Sedigraph $(\mathrm{C})$ suspension-settling techniques. The particle size fraction less than $0.063 \mathrm{~mm}$ after sieving was utilized.

Organic substances were dissolved by treatment with hydrogen peroxide; and the carbonate fraction was dissolved using diluted hydrochloric acid $(10 \%)$ in order to focus on the siliciclastic fraction of the cemented and indurated pelagic limestones and marlstones (for details, see Krenmayr 1996). The treatment of the wet sample with ultrasound inhibited the adhesion of the individual grains: approximately $1 \mathrm{~g}$ of the sample was dissolved in a 10-ml suspension liquid. The size intervals in Sedigraph were defined as 70.0-63 $\mu \mathrm{m}, 63-31.5 \mu \mathrm{m}, 31.5-16 \mu \mathrm{m}$, 16-8 $\mu \mathrm{m}, 8-4 \mu \mathrm{m}, 4-2 \mu \mathrm{m}, 2-1 \mu \mathrm{m}$, and $1-0.5 \mu \mathrm{m}$. Particles finer than $0.5 \mu \mathrm{m}$ were not considered in the grain size distribution analyses. Relative proportions of sand, silt, and clay were plotted on the ternary diagram of Folk (1974). Frequency distribution curves were produced from the percentages of each particle size range to obtain the grain size distribution patterns and provide comprehensive textural information for the sediments.

In this study, the results of the grain size analysis were graphically represented in the form of cumulative curves for all samples. The grain size distribution was described by using four parameters that were measured: (a) the arithmetic average size of all the particles in a sample (mean); (b) a range of grain sizes, percent, and the degree of scatter of these sizes around the average (standard deviation or sorting); (c) the degree of symmetry of grain size distribution (skewness); and (d) the sharpness of the grain size frequency curve (kurtosis). In this study, the above four grain size statistical parameters of mean $\left(M_{G}\right)$, standard deviation or sorting $\left(\sigma_{G}\right)$, skewness $\left(S K_{G}\right)$, and kurtosis $\left(K_{G}\right)$ were calculated for all samples using the metric scale, according to the geometric graphical methods of Folk and Ward (1957). 

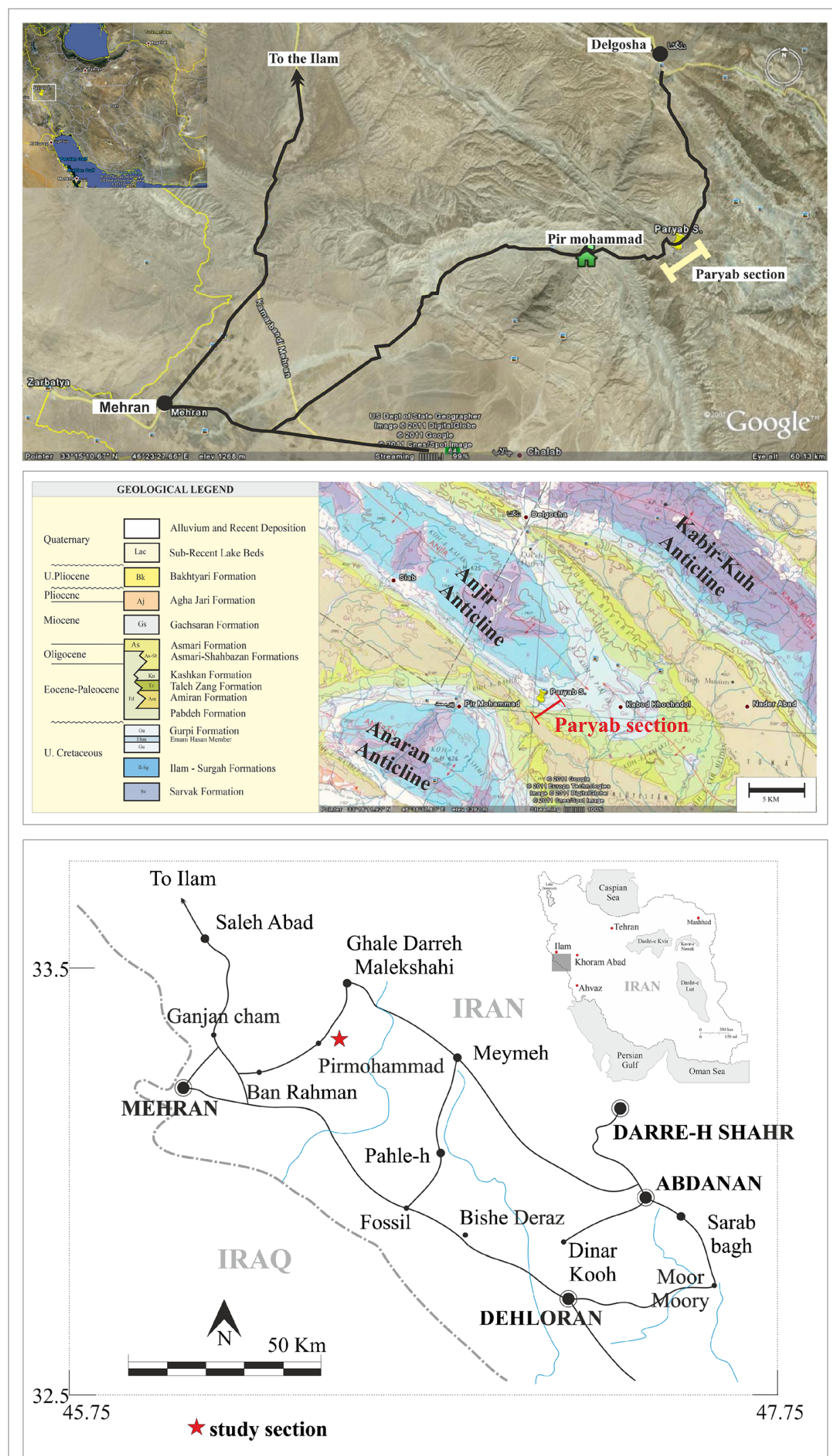

Fig. 1 Satellite images, geographical map, and road map of the Paryab section 
Fig. 2 Field photograph of the main outcrop section measured in the Pabdeh Formation (172 m thickness). To the left, gray shales of the Gurpi Formation underlie purple shales (left inset) of the lower part of the Pabdeh Formation, including the Paleocene-Eocene boundary and the PETM interval. The upper part of the Pabdeh Formation to the right comprises distinctive limestone-marl cycles (right inset)



In this study, the following mathematical calculations and statistical parameters (Tables 1 and 2, Folk and Ward 1957) were utilized for graphical measures and parameters:

\section{Geochemical and mineralogical studies}

Various geochemical and mineralogical proxies with reliable paleoenvironmental significance (e.g., Nesbitt and Young 1982; Roser and Korsch 1988; Zachos et al. 2001; Wagreich and Koukal 2019) were used in this study, including bulk and clay mineralogy (using X-ray diffraction, XRD), bulk elemental (using X-ray fluorescence, XRF), inductively coupled plasma emission spectroscopy/mass spectrometry, ICP-ES/MS) and inductively coupled plasma optical emission spectrometry, ICP-OES), and carbon and oxygen stable isotope analyses (using mass spectrometry, MS).
X-ray diffraction (XRD) Mineralogical composition was established using X-ray diffraction (XRD) with a Panalytical X'Pert PRO diffractometer $(\mathrm{Cu}$ Ka radiation, 40 kV, 40 mA, step size $0.0167,5 \mathrm{~s}$ per step). Forty-two samples were loaded in the sample holders as oriented powder.

For a general analysis of the clay mineralogy, two samples were first disaggregated with diluted $\mathrm{H}_{2} \mathrm{O}_{2}$ to remove the organic matter and subsequently treated with a $400-\mathrm{W}$ ultrasonic probe for $3 \mathrm{~min}$. The $<2-\mu \mathrm{m}$ fraction was separated by settling methods in an Atterberg cylinder, where the suspension was drained after a settling time of $24 \mathrm{~h} 33 \mathrm{~min}$ (formula after Stokes, from Köster 1964) and dried at $60^{\circ} \mathrm{C}$. Oriented clay samples were prepared by pipetting the suspensions (10-mg sample in $1 \mathrm{ml}$ of distilled water) onto glass slides and airdried. Oriented XRD mounts saturated with $\mathrm{Mg}$ and $\mathrm{K}$ ions were analyzed; and afterward, the samples were saturated with

Table 1 Geometric graphical measures (modified by Folk and Ward 1957)

\begin{tabular}{|c|c|c|c|c|c|}
\hline \multicolumn{2}{|l|}{ Sorting $\left(\sigma_{G}\right)$} & \multicolumn{2}{|l|}{ Skewness $\left(\mathrm{SK}_{\mathrm{G}}\right)$} & \multicolumn{2}{|l|}{ Kurtosis $\left(K_{G}\right)$} \\
\hline Very well sorted & $<1.27$ & Very fine skewed & -0.3 to -1.0 & Very platykurtic & $<0.67$ \\
\hline Well sorted & $1.27-1.41$ & Fine skewed & -0.1 to -0.3 & Platykurtic & $0.67-0.90$ \\
\hline Moderately well sorted & $1.41-1.62$ & Symmetrical & -0.1 to +0.1 & Mesokurtic & $0.90-1.11$ \\
\hline Moderately sorted & $1.62-2.00$ & Coarse skewed & +0.1 to +0.3 & Leptokurtic & $1.11-1.50$ \\
\hline Poorly sorted & $2.00-4.00$ & Very coarse skewed & +0.3 to +1.0 & Very leptokurtic & $1.50-3.00$ \\
\hline Very poorly sorted & $4.00-16.00$ & & & Extremely leptokurtic & $>3.00$ \\
\hline Extremely poor sorted & $>16.00$ & & & & \\
\hline
\end{tabular}


Table 2 Statistical parameters for graphical measures (after Folk and Ward 1957)

\begin{tabular}{ll}
\hline Mean & Standard deviation \\
$M_{G}=\exp \frac{\ln P_{16}+\ln P_{50}+\ln P_{84}}{3}$ & $\sigma_{G}=\exp \left(\frac{\ln P_{16}-\ln P_{84}}{4}+\frac{\ln P_{5}-\ln P_{95}}{6.6}\right)$ \\
Skewness & Kurtosis \\
$S k_{G}=\frac{\ln P_{16}+\ln P_{84}-2\left(\ln P_{50}\right)}{2\left(\ln P_{84}-\ln P_{16}\right)}+\frac{\ln P_{5}+\ln P_{95}-2\left(\ln P_{50}\right)}{2\left(\ln P_{25}-\ln P_{5}\right)}$ & $K_{G}=\frac{\ln P_{5}+\ln P_{95}}{2.44\left(\ln P_{25}-\ln P_{75}\right)}$ \\
\hline
\end{tabular}

ethylene glycol (EG) and glycerol (Gly) at $60^{\circ} \mathrm{C}$ for $12 \mathrm{~h}$. The saturation with ethylene glycol and glycerol was carried out to identify expandable clay minerals like smectite and vermiculite (Moore and Reynolds 1997). Additionally, the samples were heated to $550{ }^{\circ} \mathrm{C}$ to destroy kaolinite and expandable clay minerals (Moore and Reynolds 1997).

Inductively coupled plasma emission spectroscopy/mass spectrometry (ICP-ES/MS) and inductively coupled plasma optical emission spectrometry (ICP-OES) In the present study, samples were pulverized for bulk rock geochemistry. The bulk rock analyses were conducted in Bureau Veritas Ltd. (former Acme) Analytical Laboratories Canada using inductively coupled plasma emission spectroscopy/mass spectrometry (ICP-ES/MS).

X-ray fluorescence (XRF) In addition, 62 samples were utilized for inspection with a handheld XRF (Bruker Tracer IV); screening takes $420 \mathrm{~s}$ (7 min) per sample. Internal calibration by ICP analyses was used for elements like $\mathrm{Ca}, \mathrm{Mg}, \mathrm{Si}, \mathrm{Al}$,
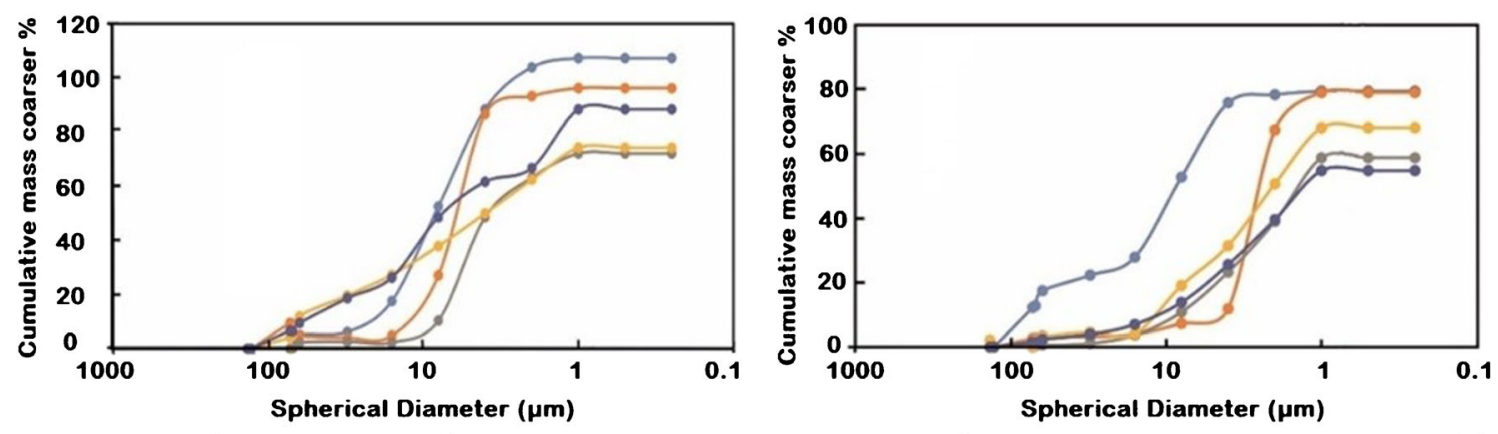

$\rightarrow$ py-2 $\rightarrow$ py-4 $\rightarrow$ py-5 $\rightarrow$ py-7 $\rightarrow$ py-8

$\rightarrow$ py-9 $\rightarrow$ py-11 $\rightarrow$ py-12 $\multimap$ py-13A $\rightarrow$ py-14
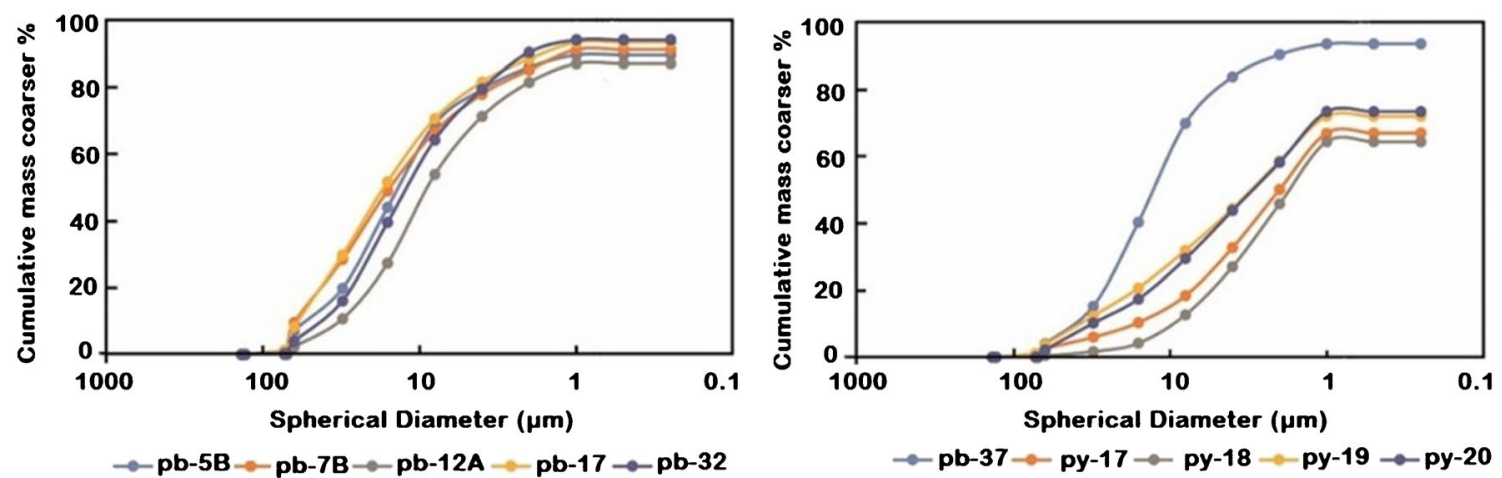

$\leadsto$ pb-5B $\leadsto$ pb-7B $\multimap$ pb-12A $\multimap$ pb-17 $\multimap$ pb-32

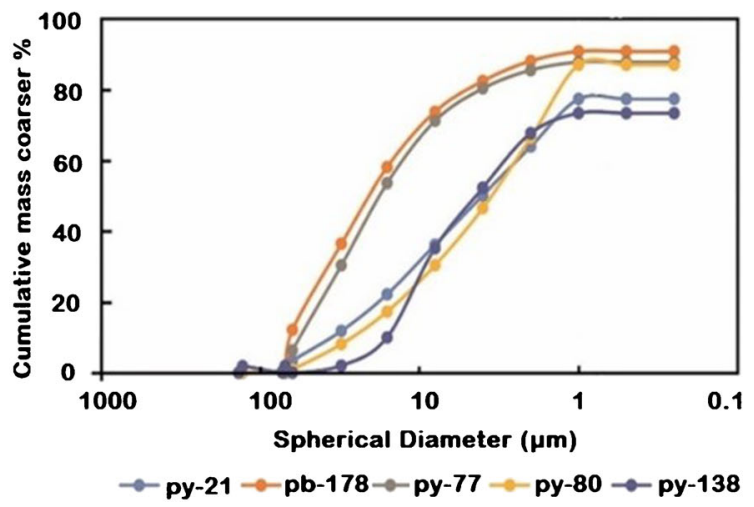

Fig. 3 Grain size distribution cumulative curves 
Fig. 4 Bivariate plots of statistical parameters of the studied samples, A standard deviation versus mean, $\mathbf{B}$ skewness versus mean, $\mathbf{C}$ kurtosis versus mean, $\mathbf{D}$ standard deviation versus skewness, and $\mathbf{E}$ kurtosis versus skewness
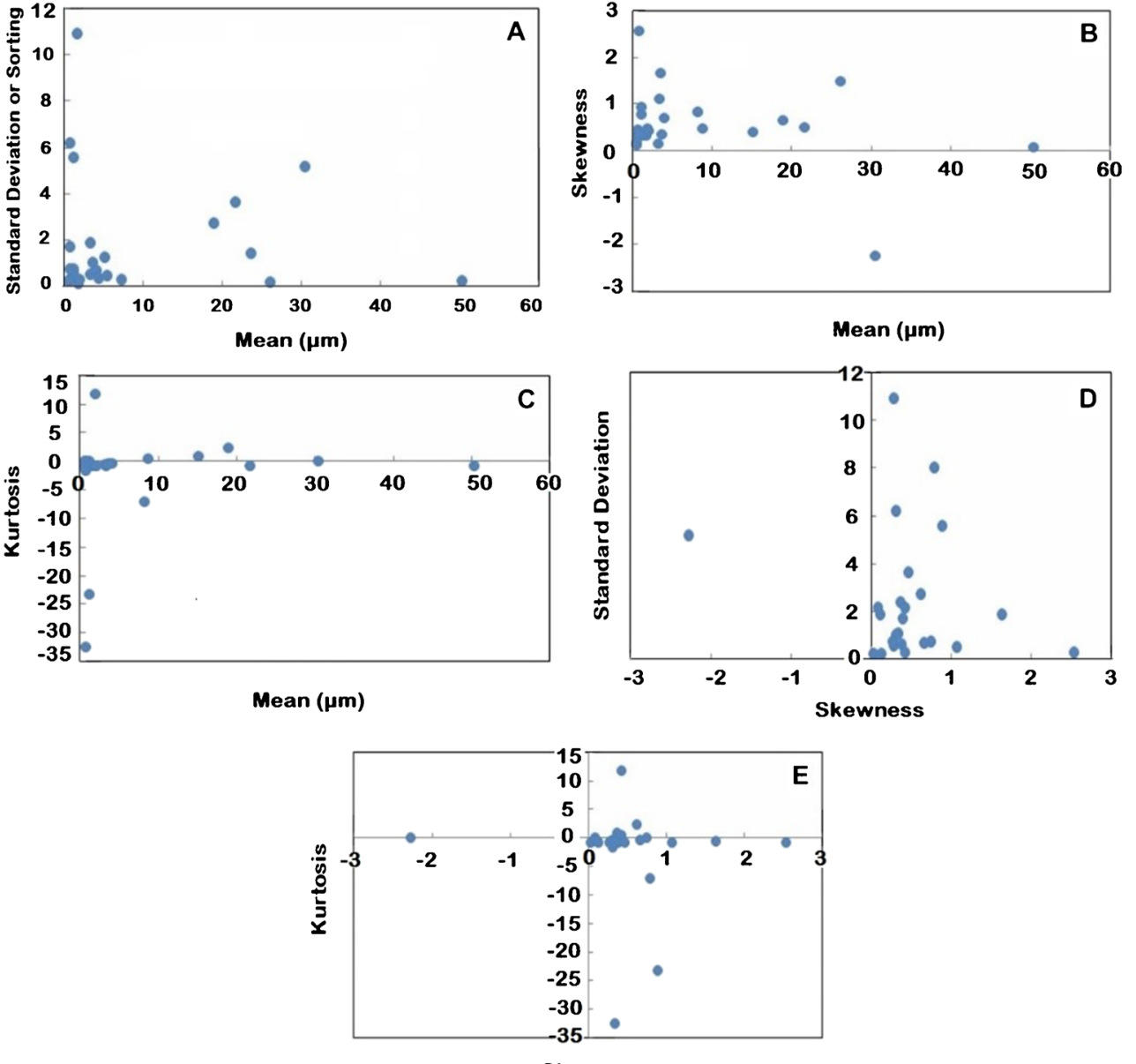

Skewness

$\mathrm{Mn}, \mathrm{Ti}$, and $\mathrm{Zr}$. In general, errors after calibration were in the range of $1-3 \%$ of the measured values.

Carbon and oxygen stable isotope analyses Fifty-nine bulk sediment samples were analyzed for stable carbon and oxygen isotopes using a Thermo Fisher DeltaPlusXL mass spectrometer equipped with a GasBench II according to the procedure of Spötl and Vennemann (2003) at the Institute of Geology, University of Innsbruck (Austria). The results were calibrated using the NBS 19, CO1, and CO8 standard reference materials and reported on the VPDB scale; analytical precision was at $0.05 \mathrm{wt} \%$ for $\delta^{13} \mathrm{C}$. The long-term 1-sigma uncertainty of the carbon and oxygen isotope data was 0.06 and $0.08 \%$, respectively. The carbon isotope data was used for isotope stratigraphy and correlated to the global variation of $\delta^{13} \mathrm{C}$ in seawater during the Cenozoic and around the PETM (Jenkyns et al. 1994; Zachos et al. 2008; Zeebe et al. 2014). Due to the possible influence of diagenesis on oxygen isotopes, those values were not used further in this study.

Carbonate content and total organic carbon (TOC) In this study, 179 sediment samples were chosen from outcrops of the Pabdeh Formation in order to measure the TOC and
$\mathrm{CaCO}_{3}$ contents. The carbonate content of all samples (Azami et al. 2018) was measured by using diluted hydrochloric acid (error range of $1 \mathrm{wt} \% \mathrm{CaCO}_{3}$ ) and correlated to contents of total organic carbon (TOC), determined at $550{ }^{\circ} \mathrm{C}$ using a LECO carbon analyzer (Department of Environmental Geosciences/EDGE, University of Vienna, Austria). Samples were analyzed in duplicates or in triplicates if double measurements were above a relative standard deviation of $\pm 5 \mathrm{wt} \% 2.9$. TOC versus carbonate content diagrams (Ricken 1996) are used for interpretation of the type of sedimentation and cycles, i.e., dilution versus production control.

\section{Results}

\section{Grain size statistics}

Grain size statistical analysis shows no significant overall trend of 25 samples of very fine- to fine-grained silt and clay from base to top of the section. Moreover, a unimodal character-with peaks between 0.53 (clay) and $22.39 \mu \mathrm{m}$ (silt) at an average of $4.84 \mu \mathrm{m}$ (fine-grained silt) (Fig. 3) - 
was determined from cumulative mass coarser percentage data.

Statistical parameters (mean, standard deviation, skewness, and kurtosis) calculated from the grain size distribution curves (Folk and Ward 1957) are as follows.

In the studied samples, the mean values $\left(\mathbf{M}_{\mathbf{Z}}\right)$ range from 0.66 (clay grain size) to $50.48 \mu \mathrm{m}$ (Fig.3).

Figure 4 shows that the graphic standard deviation values $\left(\sigma_{G}\right)$ of Paryab samples range from 0.10 to $10.87 \mu \mathrm{m}$ (with an average $2.19 \mu \mathrm{m}$ ). Most of the samples display good sorting, but sorting changes from very well sorted to very poorly sorted in some samples from base to top of the section.

The values of graphic skewness $\left(S K_{G}\right)$ in the studied samples change from -2.262 (very finely skewed) to 2.542 (very coarsely skewed), with an average of 0.436 (very coarsely skewed).

Graphic kurtosis $\left(K_{G}\right)$ is calculated by comparing the spread or the sorting of the tails in the central part of the distribution curve to the spread in the tails (Baiyegunhi et al. 2017). Most of the samples range from -32.62 to 11.66 (with an average -1.99 ), which fall in the very platykurtic to

Table 3 Cumulative percentages of sand, silt, and clay size grains of studied samples

\begin{tabular}{llll}
\hline Sample number & Sand wt\% & Silt wt\% & Clay wt\% \\
\hline Py-2 & 5 & 83 & 18.8 \\
Py-4 & 4.9 & 81.3 & 9.6 \\
Py-5 & 2.3 & 46.0 & 25.8 \\
Py-7 & 11.9 & 37.8 & 24.2 \\
Py-8 & 9.4 & 52.0 & 26.6 \\
Py-9 & 17.4 & 58.3 & 3.6 \\
Py-11 & 3.3 & 8.5 & 67.1 \\
Py-12 & 0.6 & 22.6 & 35.5 \\
Py-13A & 3.1 & 28.3 & 36.6 \\
Py-14 & 2.3 & 23.2 & 29.2 \\
PB-5B & 7 & 72.4 & 10.3 \\
PB-7B & 9.5 & 68.5 & 13.3 \\
PB-12A & 2.3 & 69 & 15.8 \\
PB-17 & 8.2 & 73.4 & 11.9 \\
PB-32 & 3.9 & 75.6 & 14.7 \\
PB-37 & 4.0 & 79.8 & 9.8 \\
Py-17 & 2.6 & 30.1 & 34.3 \\
Py-18 & 0.5 & 26.5 & 37.4 \\
Py-19 & 3.7 & 40.7 & 27.6 \\
Py-20 & 2.2 & 41.6 & 29.6 \\
Py-21 & 3.3 & 46.9 & 27.2 \\
PB-178 & 12.1 & 70.4 & 8.4 \\
Py-77 & 6.3 & 74.1 & 7.5 \\
Py-80 & 0.9 & 45.7 & 40.5 \\
Py-138 & -0.6 & 52.9 & 21.1 \\
\hline & & & \\
\hline
\end{tabular}

extremely leptokurtic (average extremely leptokurtic) fields. These values are correlated with sorting ranges of studied samples.

The bivariate plot of graphic standard deviation against mean (Fig. 4A) in the studied samples shows that most of the Paryab samples are very well- to moderately sorted fine silt to clay. Other bivariate plots of skewness versus mean, kurtosis versus mean, standard deviation versus skewness, and kurtosis versus skewness (Fig. 4B to E) will be used to determine the depositional setting.

Table 3 presents cumulative percentages of sand, silt, and clay size grains. The ternary sand-silt-clay plot of Folk (1974) provides a graphic textural classification of the sediments based on these grain size classes. Figure 5 shows that the studied samples mostly plot in the clay (11 samples) and silt (8 samples) fields; but some samples plot in the sandy silt (3 samples) and sandy mud (2 samples) fields.

\section{XRD result and mineral composition}

The XRD results of the studied section indicate that calcite, quartz, ankerite, dolomite, and the clay minerals illite, chlorite, mixed-layer chlorite/smectite, and kaolinite are the main mineral components of these samples throughout the section (Fig. 6). In almost all of the studied samples, calcite is the most abundant mineral, indicated by the intense $3.03 \AA$ peak. Quartz is signaled by the main reflection at $3.34 \AA$ and ankerite and dolomite by their peaks at $2.88 \AA$ and $2.89 \AA$, respectively. Chlorite is indicated by the peaks at $14.15 \AA, 7.14 \AA$, $4.75 \AA$, and $3.54 \AA$, which do not change position during treatments. Illite peaks at $10 \AA, 4.95 \AA$, and $3.3 \AA$ also maintain their positions. Kaolinite peaks at $7.12 \AA$ and $3.57 \AA$ disappear after heating to $550{ }^{\circ} \mathrm{C}$. A broad peak in the very



Fig. 5 Ternary sand-silt-clay diagram (Folk 1974) 

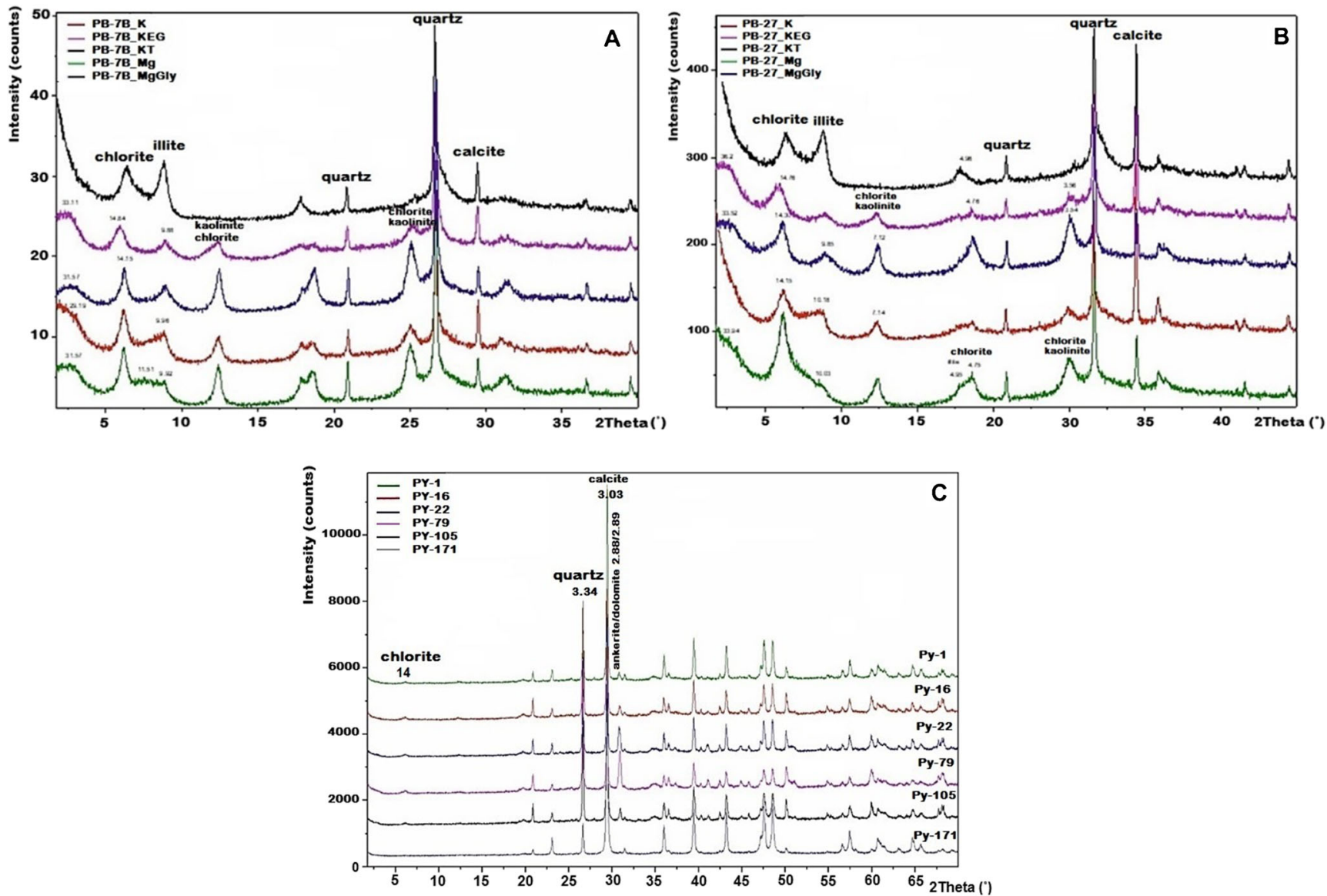

Fig. 6 X-ray diffraction patterns of the clay fraction of samples PB-7B (A) and PB-27 (B) saturated with $\mathrm{Mg}$ (green), $\mathrm{K}$ (red), $\mathrm{Mg}$ and glycerol (MgGly, blue), and $\mathrm{K}$ and ethylene glycol (KEG, magenta) and heated to

low 2-theta range indicates the presence of a mixed-layer mineral, most likely chlorite/smectite.

\section{Sediment geochemistry results}

Major and trace elemental analyses of thirty shale and limestone samples were carried out by XRF technique; and the results are listed in Tables 4 and 5. From Table 4, it is apparent that most of the studied samples are rich in $\mathrm{CaO}$ (38.52$67.67 \mathrm{wt} \%$ ) and $\mathrm{SiO}_{2}(18.41-39.67 \mathrm{wt} \%)$.

In contrast, they have low contents of $\mathrm{Al}_{2} \mathrm{O}_{3}(2.94$ $5.69 \mathrm{wt} \%), \mathrm{Fe}_{2} \mathrm{O}_{3}(1.53-6.93 \mathrm{wt} \%), \mathrm{MgO}(5.48-$ $12.39 \mathrm{wt} \%), \mathrm{K}_{2} \mathrm{O}(0.24-2.14 \mathrm{wt} \%), \mathrm{TiO}_{2}(0.18-0.99 \mathrm{wt} \%)$, $\mathrm{P}_{2} \mathrm{O}_{5}(0-0.22 \mathrm{wt} \%), \mathrm{MnO}(0.026-0.0 .094 \mathrm{wt} \%)$, and $\mathrm{Cr}_{2} \mathrm{O}_{3}$ (0.003-0.072 wt\%) (Table 4).

More than 15 trace and rare earth elements were analyzed by XRF in the studied shale and limestone samples. The results of some these elements are introduced in Table 5. Elements such as $\mathrm{Zr}$ (3-55 ppm), $\mathrm{Cu}$ (33-64 ppm), Zn (54119 ppm), Ni (27-218 ppm), Cr (29-717 ppm), and Mo (08 ppm) (Table 5) are most important to unravel paleoenvironment and paleoclimate implications.
$550{ }^{\circ} \mathrm{C}$ (KT, black); C X-ray diffraction patterns of some selected bulk samples from the Pabdeh Formation, Paryab section; $d$ values in $\AA$

Percentages of three important major oxides $\left(\mathrm{SiO}_{2}, \mathrm{Al}_{2} \mathrm{O}_{3}\right.$, and $\mathrm{CaO}$ ) (Fig. 7) are investigated from base to top of the section. The values measured were in the following ranges: $\mathrm{SiO}_{2}$ from 18.41 to $39.67 \mathrm{wt} \% ; \mathrm{Al}_{2} \mathrm{O}_{3}$ from 2.94 to $5.69 \mathrm{wt} \%$; and $\mathrm{CaO}$ from 38.52 to $67.67 \mathrm{wt} \%$. The $\mathrm{Al}$ and $\mathrm{Si}$ lithogeochemical profiles strongly correlate together, but the $\mathrm{Ca}$ profile does not display a clear correlation with $\mathrm{Al}$ and $\mathrm{Si}$ (Fig. 8).

Aluminum correlates with $\mathrm{Fe}$ and $\mathrm{K}_{2} \mathrm{O}$ (these elements typically are associated with clay minerals $)\left(\mathrm{R}^{2}=0.8151\right.$ and 0.8738 , respectively, Fig. 8). The positive correlation between $\mathrm{Al}$ and $\mathrm{Si}\left(\mathrm{R}^{2}=0.6363\right.$, Fig. 8) indicates that the major Si-bearing component is detrital quartz; and the Si content increases as the particle sizes increase. In Fig. 8, the negative correlation between $\mathrm{Ca}$ and $\mathrm{Al}$ and $\mathrm{Si}$ is also seen $\left(\mathrm{R}^{2}=0.794\right.$ and 0.9198 , respectively).

\section{Stable isotope}

The prominent negative excursion in $\delta^{13} \mathrm{C}$ values at $69.1 \mathrm{~m}$ of the section is indicated by a shift of up to $-2 \%$ from values around $2.0 \%$ to $-0.2 \%$. This carbon isotope 
Table 4 Major (weight percent) oxide concentrations for shale and limestone samples of the Paryab section (handheld XRF analyses; percentages recalculated to $100 \%$ without considering non-measurable elements such as $\mathrm{Na}$ )

\begin{tabular}{|c|c|c|c|c|c|c|c|c|c|c|c|}
\hline Sample no. & Thickness (m) & $\mathrm{MgO}$ & $\mathrm{Al}_{2} \mathrm{O}_{3}$ & $\mathrm{SiO}_{2}$ & $\mathrm{P}_{2} \mathrm{O}_{5}$ & $\mathrm{~K}_{2} \mathrm{O}$ & $\mathrm{CaO}$ & $\mathrm{TiO}_{2}$ & $\mathrm{Cr}_{2} \mathrm{O}_{3}$ & $\mathrm{MnO}$ & $\mathrm{Fe}_{2} \mathrm{O}_{3}$ \\
\hline Py-2 & 7.5 & 10.07 & 5.41 & 26.22 & 0.22 & 1.51 & 50.88 & 0.68 & 0.015 & 0.062 & 4.64 \\
\hline Py-4 & 17.5 & 9.41 & 5.12 & 36.63 & 0.18 & 1.60 & 38.76 & 0.96 & 0.03 & 0.067 & 6.93 \\
\hline Py-5 & 22.5 & 10.86 & 5.57 & 29.10 & 0.19 & 1.85 & 46.00 & 0.75 & 0.02 & 0.066 & 5.32 \\
\hline Py-8 & 37.5 & 5.48 & 5.13 & 28.82 & 0.10 & 1.58 & 52.49 & 0.83 & 0.01 & 0.069 & 5.28 \\
\hline Py-9 & 42.5 & 10.13 & 5.69 & 33.14 & 0.21 & 2.14 & 40.71 & 0.99 & 0.03 & 0.068 & 6.64 \\
\hline Py-11 & 52.5 & 8.62 & 5.41 & 34.55 & 0.11 & 1.79 & 42.32 & 0.82 & 0.02 & 0.066 & 5.99 \\
\hline Py-12 & 57.5 & 10.86 & 4.76 & 35.75 & 0.18 & 1.37 & 41.80 & 0.65 & 0.016 & 0.072 & 4.24 \\
\hline Py-14 & 67.5 & 9.47 & 4.99 & 36.41 & 0.114 & 1.6 & 41.54 & 0.72 & 0.016 & 0.055 & 4.61 \\
\hline Py-17 & 82.5 & 10.08 & 5.06 & 34.11 & 0.147 & 1.64 & 43.59 & 0.77 & 0.02 & 0.061 & 4.18 \\
\hline Py-18 & 87.5 & 11.68 & 4.83 & 28.49 & 0.163 & 1.49 & 48.28 & 0.70 & 0.013 & 0.078 & 3.97 \\
\hline Py-19 & 92.5 & 10.76 & 4.83 & 25.75 & 0.072 & 1.16 & 51.51 & 0.71 & 0.019 & 0.091 & 4.8 \\
\hline Py-20 & 97.5 & 8.53 & 5.23 & 28.72 & 0.111 & 1.52 & 50.01 & 0.75 & 0.021 & 0.072 & 4.71 \\
\hline Py-21 & 102.5 & 12.39 & 6.05 & 33.35 & 0.139 & 1.43 & 38.52 & 0.90 & 0.072 & 0.094 & 6.67 \\
\hline Py-23 & 107.5 & 11.28 & 4.15 & 24.21 & 0.112 & 0.56 & 55.38 & 0.45 & 0.026 & 0.067 & 3.46 \\
\hline Py-26 & 112.5 & 7.60 & 4.41 & 25.42 & 0.81 & 0.94 & 55.35 & 0.59 & 0.025 & 0.069 & 4.19 \\
\hline Py-32 & 120.3 & 9.85 & 3.71 & 21.78 & 0.08 & 0.68 & 60.09 & 0.4 & 0.013 & 0.071 & 3.09 \\
\hline Py-40 & 124.13 & 8.88 & 3.79 & 27.04 & 0.004 & 0.97 & 54.23 & 0.62 & 0.013 & 0.068 & 4.04 \\
\hline Py-47 & 128.57 & 6.74 & 5.6 & 38.46 & 0.049 & 1.79 & 40.37 & 0.95 & 0.030 & 0.053 & 5.78 \\
\hline Py-58 & 132.46 & 9.64 & 3.16 & 20.26 & 0.11 & 0.24 & 64.02 & 0.27 & 0.006 & 0.039 & 2 \\
\hline Py-67 & 136.39 & 6.62 & 5.29 & 39.67 & 0.063 & 1.61 & 40.35 & 0.85 & 0.038 & 0.049 & 5.17 \\
\hline Py-74 & 140.68 & 9.85 & 2.97 & 24.63 & 0 & 0.43 & 58.68 & 0.37 & 0.006 & 0.034 & 2.71 \\
\hline Py-83 & 144.27 & 8.59 & 4.94 & 29.79 & 0.082 & 1.47 & 50.29 & 0.69 & 0.019 & 0.040 & 3.80 \\
\hline Py-102 & 148.18 & 9.56 & 2.94 & 21.82 & 0.013 & 0.53 & 61.95 & 0.37 & 0.018 & 0.038 & 2.48 \\
\hline Py-117 & 152.06 & 7.27 & 4.59 & 29.41 & 0.0064 & 1.29 & 51.93 & 0.69 & 0.039 & 0.041 & 4.39 \\
\hline Py-130 & 156.04 & 8.25 & 3.26 & 18.41 & 0.193 & 0.164 & 67.67 & 0.23 & 0.003 & 0.038 & 1.63 \\
\hline Py-139 & 160.27 & 10.17 & 4.01 & 27.78 & 0 & 0.71 & 52.32 & 0.53 & 0.03 & 0.048 & 4.14 \\
\hline Py-147 & 164.49 & 10.13 & 4.04 & 30.69 & 0.011 & 1.03 & 49.08 & 0.62 & 0.023 & 0.047 & 4.1 \\
\hline Py-159 & 169.74 & 8.67 & 3.34 & 21.64 & 0.021 & 0.65 & 62.31 & 0.48 & 0.014 & 0.028 & 2.51 \\
\hline Py-168 & 171.68 & 8.17 & 3.27 & 21.27 & 0.21 & 0.138 & 64.95 & 0.18 & 0.007 & 0.027 & 1.53 \\
\hline Рy-170 & 172.1 & 8.92 & 2.81 & 18.70 & 0.106 & 0.114 & 67.06 & 0.25 & 0.009 & 0.026 & 1.84 \\
\hline
\end{tabular}

excursion (CIE) coincides, according to nannofossil biostratigraphy, with the PETM interval (Azami et al. 2018). This initial rapid negative carbon isotope excursion is typical of continuous PETM sections. In the interval higher up, $\delta^{13} \mathrm{C}$ values increase again. Carbon isotope values then fluctuate between 0 and $1 \%$ without showing further distinct peaks or plateaus (Fig. 9B). $\delta^{18} \mathrm{O}$ values show a rather noisy pattern but correlate to the negative carbon isotope peak around the PETM interval.

\section{Carbonate and organic carbon content}

The Paryab section sediments have TOC contents of $0.17-$ $0.58 \mathrm{wt} \%$ that are lower than the average shale value of $0.8 \mathrm{wt} \%$ (Mason and Moore 1982) and $\mathrm{CaCO}_{3}$ ranging from 40.5 to $79.5 \mathrm{wt} \%$ (for details on carbonate values, see Azami et al. 2018). The TOC profile indicates little variation throughout the analyzed section, but in the lower part of the section, TOC contents are lower than in the upper part of section to $142.6 \mathrm{~m}$. Above $142.6 \mathrm{~m}$ to top of the section, TOC content decreased again (Fig. 9B). In the TOC-CaCO 3 cross-plot diagram, the correlation patterns show different types of depositional dilution and concentration processes related to rhythmic beds (Ricken 1993, 1996; Khatun 2007). In this study, the TOC content of the studied samples is negatively correlated with the $\mathrm{CaCO}_{3}$ values $\left(R^{2}=0.0405\right)$ (Fig. 10). Based on low content and minimal variations in total organic carbon (TOC), the deep-water pelagic to hemipelagic shales, marls, and limestones of the Paryab section plot between the calcareous and non-calcareous members. Thus, the TOC concentration in the sediment is largely determined by the flux of carbonate and clastic sources. 
Table 5 Trace element concentrations (parts per million $(\mathrm{ppm})$ ) for shale and limestone samples from handheld XRF analyses

\begin{tabular}{|c|c|c|c|c|c|c|c|c|c|c|c|c|c|c|}
\hline Sample no. & $\mathrm{Ni}$ & $\mathrm{Cu}$ & $\mathrm{Zn}$ & As & $\mathrm{Rb}$ & $\mathrm{Sr}$ & $\mathrm{Zr}$ & Mo & $\mathrm{Cr}$ & $\mathrm{Cd}$ & $\mathrm{Mn} / \mathrm{Al}$ & $\mathrm{Ti} / \mathrm{Al}$ & $\mathrm{Si} / \mathrm{Al}$ & $\mathrm{Zr} / \mathrm{Al}$ \\
\hline Py-2 & 99 & 49 & 101 & 0 & 37 & 1010 & 41 & 0 & 169.54 & 0 & 0.007 & 0.11 & 5.49 & 0.0004 \\
\hline Py-4 & 197 & 50 & 115 & 7 & 34 & 841 & 54 & 3 & 340.54 & 129 & 0.009 & 0.17 & 8.1 & 0.0006 \\
\hline Py-5 & 145 & 39 & 89 & 13 & 32 & 691 & 54 & 0 & 216.31 & 212 & 0.008 & 0.12 & 5.92 & 0.0005 \\
\hline Py- 8 & 114 & 52 & 108 & 0 & 37 & 1110 & 44 & 3 & 146.15 & 0 & 0.009 & 0.14 & 6.36 & 0.0005 \\
\hline Py-9 & 157 & 33 & 86 & 0 & 32 & 622 & 44 & 0 & 292.31 & 399 & 0.008 & 0.15 & 6.59 & 0.0004 \\
\hline Py-11 & 152 & 54 & 119 & 21 & 41 & 923 & 47 & 1 & 252.85 & 23 & 0.008 & 0.13 & 7.23 & 0.0005 \\
\hline Py-12 & 103 & 37 & 79 & 10 & 26 & 725 & 31 & 8 & 157.85 & 29 & 0.1 & 0.12 & 8.5 & 0.0003 \\
\hline Py-14 & 111 & 47 & 81 & 13 & 30 & 793 & 33 & 1 & 160.77 & 269 & 0.008 & 0.13 & 8.26 & 0.0004 \\
\hline Py-17 & 94 & 37 & 78 & 0 & 30 & 776 & 35 & 2 & 191.46 & 297 & 0.008 & 0.13 & 7.63 & 0.0004 \\
\hline Py-18 & 71 & 64 & 73 & 0 & 28 & 728 & 25 & 3 & 134.46 & 244 & 0.011 & 0.13 & 6.68 & 0.0003 \\
\hline Py-19 & 101 & 43 & 85 & 0 & 24 & 742 & 27 & 4 & 187.08 & 126 & 0.013 & 0.13 & 6.04 & 0.0003 \\
\hline Py-20 & 79 & 44 & 83 & 9 & 28 & 801 & 32 & 2 & 207.54 & 97 & 0.009 & 0.13 & 6.22 & 0.0003 \\
\hline Py-21 & 218 & 58 & 97 & 0 & 27 & 776 & 41 & 3 & 717.62 & 200 & 0.011 & 0.13 & 6.24 & 0.0004 \\
\hline Py-23 & 84 & 41 & 74 & 0 & 13 & 836 & 17 & 2 & 279.16 & 0 & 0.011 & 0.08 & 6.61 & 0.0002 \\
\hline Py-26 & 94 & 49 & 88 & 5 & 26 & 823 & 30 & 0 & 328.85 & 0 & 0.011 & 0.12 & 6.53 & 0.0004 \\
\hline Py-32 & 59 & 43 & 71 & 2 & 17 & 753 & 20 & 6 & 152.00 & 0 & 0.013 & 0.09 & 6.65 & 0.0003 \\
\hline Py-40 & 86 & 45 & 78 & 0 & 27 & 752 & 32 & 3 & 143.23 & 0 & 0.012 & 0.14 & 8.08 & 0.0004 \\
\hline Py-47 & 173 & 56 & 95 & 0 & 41 & 564 & 55 & 5 & 321.54 & 26 & 0.006 & 0.15 & 7.78 & 0.0005 \\
\hline Рy-58 & 35 & 38 & 65 & 0 & 7 & 835 & 9 & 5 & 73.08 & 0 & 0.008 & 0.08 & 7.26 & 0.0002 \\
\hline Py-67 & 190 & 61 & 101 & 23 & 40 & 640 & 52 & 3 & 404.85 & 25 & 0.006 & 0.14 & 8.49 & 0.0005 \\
\hline Py-74 & 47 & 45 & 58 & 0 & 14 & 827 & 18 & 4 & 70.15 & 0 & 0.008 & 0.11 & 9.39 & 0.0003 \\
\hline Py- 83 & 93 & 47 & 100 & 0 & 38 & 862 & 40 & 3 & 211.93 & 0 & 0.006 & 0.12 & 6.83 & 0.0004 \\
\hline Py-102 & 50 & 41 & 61 & 0 & 19 & 935 & 17 & 3 & 192.92 & 0 & 0.009 & 0.11 & 8.4 & 0.0003 \\
\hline Py-117 & 131 & 56 & 117 & 3 & 33 & 863 & 39 & 4 & 404.85 & 0 & 0.006 & 0.13 & 7.25 & 0.0004 \\
\hline Py-130 & 27 & 36 & 58 & 1 & 7 & 1000 & 5 & 6 & 29.23 & 0 & 0.008 & 0.06 & 6.39 & 0.0001 \\
\hline Py-139 & 139 & 41 & 62 & 0 & 18 & 620 & 26 & 4 & 302.54 & 43 & 0.008 & 0.12 & 7.84 & 0.0003 \\
\hline Рy-147 & 109 & 40 & 58 & 8 & 21 & 643 & 34 & 1 & 242.62 & 51 & 0.008 & 0.14 & 8.6 & 0.0004 \\
\hline Py-159 & 66 & 40 & 83 & 0 & 18 & 888 & 16 & 3 & 143.23 & 0 & 0.006 & 0.13 & 7.33 & 0.0003 \\
\hline Py-168 & 37 & 37 & 54 & 0 & 6 & 1150 & 3 & 8 & 77.46 & 0 & 0.006 & 0.05 & 7.36 & 0.00004 \\
\hline Py-170 & 50 & 43 & 61 & 5 & 10 & 972 & 5 & 5 & 103.77 & 0 & 0.006 & 0.08 & 7.53 & 0.0001 \\
\hline
\end{tabular}

Three bivariate diagrams $\mathrm{V} / \mathrm{Cr}-\mathrm{Ni} / \mathrm{Co}, V / \mathrm{V}+\mathrm{Ni}-\mathrm{Ni} / \mathrm{Co}$, and $\mathrm{Mo}-\mathrm{Ni} / \mathrm{Co}$ have been assembled based on ICP analysis data of nine Pabdeh Formation samples from base to top (Table 6). In these bivariate diagrams (Fig. 11A, B, C), the studied shale and limestone samples of the Paryab section plot in the suboxic/anoxic field with very little oxygen. Figure 11D



Fig. $7 \mathrm{Al}_{2} \mathrm{O}_{3}-\mathrm{SiO}_{2}-\mathrm{CaO}$ triangular plot of Pabdeh Formation samples. The purple dots are samples' location in the diagram shows the $\mathrm{P}_{2} \mathrm{O}_{5}-\mathrm{Al}_{2} \mathrm{O}_{3}$ bivariate diagram of the studied samples. In this diagram, most of the studied shales and limestones plot in the field of deep marine depositional environments.

\section{Discussion}

\section{Sedimentology and depositional environment}

The studied section of the Pabdeh Formation consists of rhythmic pelagic marl-limestone beds with different thicknesses associated with hemipelagic to pelagic fine-grained (clay to silt) shaly deposition. Statistical parameters result on Paryab section shows no significant overall trend in grain size and shows the consistent depositional process during which the sediment particles settled through the water column. The graphic mean is the average size of grains and applies as the index of energy conditions (Passega 1964). The measured mean size variations may relate to fluctuations in the energy conditions during deposition and thus reflect a sea level proxy (Wagreich and Koukal 2019). Abundance of fine-grained sediments and absence of coarser-grained sediments indicate in general a low energy depositional environment (Boggs 2009; Baiyegunhi et al. 2017). The hydrodynamic energy changes of 

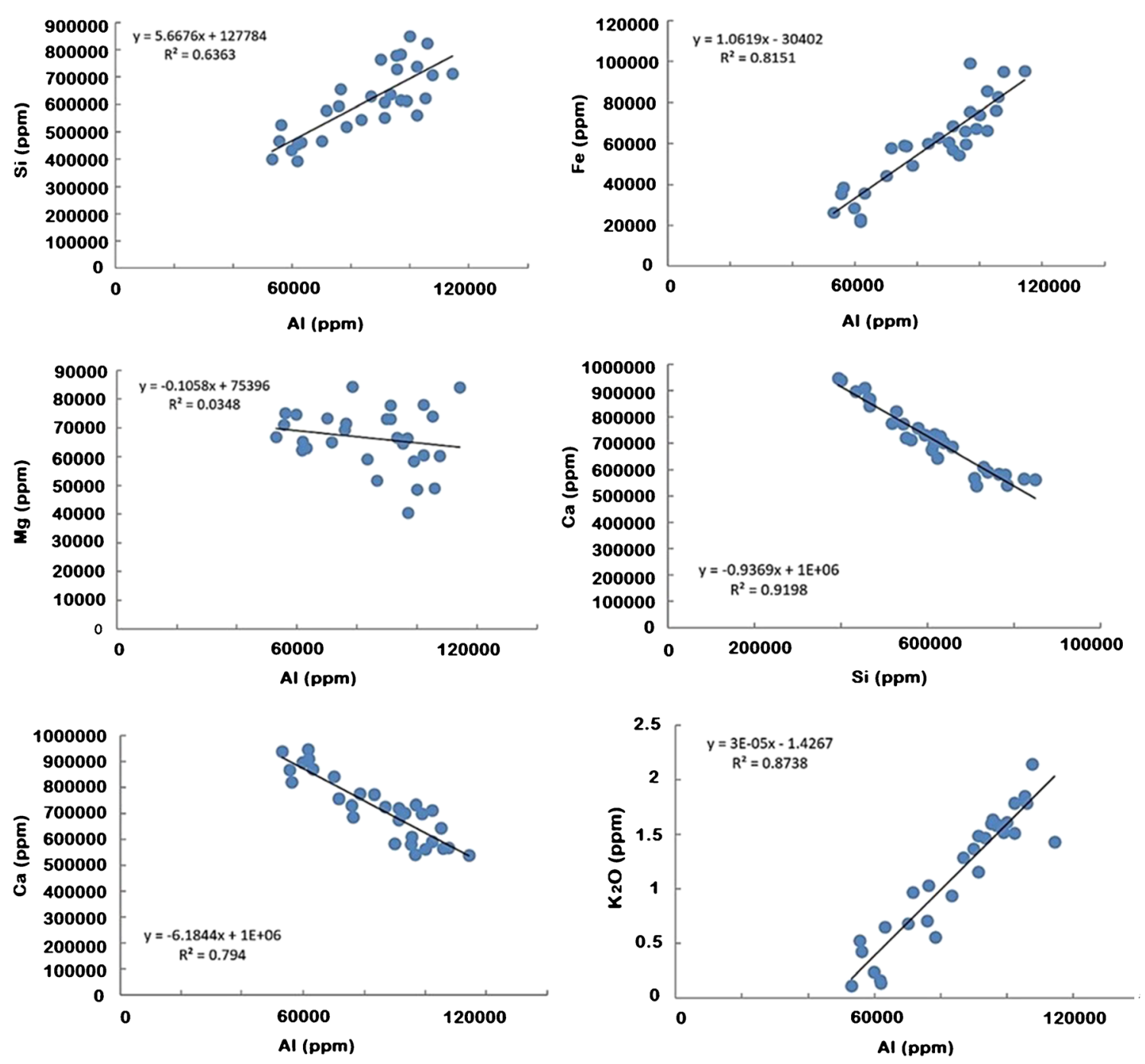

Fig. 8 Element bivariate plots of studied samples

the depositional environment control the sorting of sediments (Baiyegunhi et al. 2017). The hydrodynamic energy changes of the depositional environment control the sorting of sediments (Baiyegunhi et al. 2017).

The current energy fluctuations in marine environment or influx of clastic sediments could result in very well sorted to very poorly sorted (in some samples change) of grains (Angusamy and Rajamanickam 2006; Rajesh et al. 2007) with higher and coarser clastic influx in more poorly sorted layers. Very well to moderately sorted fine silt to clay sediment indicates that sediment particle transport took a long time, probably as suspension of fine-grained particles, and thus the studied samples were deposited in a more quiet, deep marine environment. In this environment, reworking of sediments was due to the presence of weak bottom currents as well as coarser size sediment (very fine-grained sands) influx to the environment by dilute turbidity flows.

Based on XRD analysis, the main mineral components of these samples are calcite, quartz, ankerite, dolomite, and the clay minerals. Thus, the sediments can be classified as marls, being mineralogically a mixture of calcite, quartz, and clay minerals in varying quantities. XRF analysis shows that the proportions of carbonate, clay minerals, and quartz vary in the studied shale and limestone samples. This is shown by the $\mathrm{Al}_{2} \mathrm{O}_{3}-\mathrm{SiO}_{2}-\mathrm{CaO}$ ternary diagram (Fig. 7), where the majority of samples plot close to $\mathrm{SiO}_{2}-\mathrm{CaO}$ line. These samples represent variable mixing between shale and carbonate in the source areas, documented also by the cyclic alternating shale and marl-limestone beds in the studied succession.

\section{Depositional type and sea level fluctuations}

A negative excursion in $\delta 13 \mathrm{C}$ values in the study section, known as the carbon isotope excursion (CIE), coincides, according to nannofossil biostratigraphy, with the PETM interval (Azami et al. 2018). The organic matter content in sedimentary rocks is usually measured as the total organic carbon value (TOC content) and expressed as a percentage of the dry 


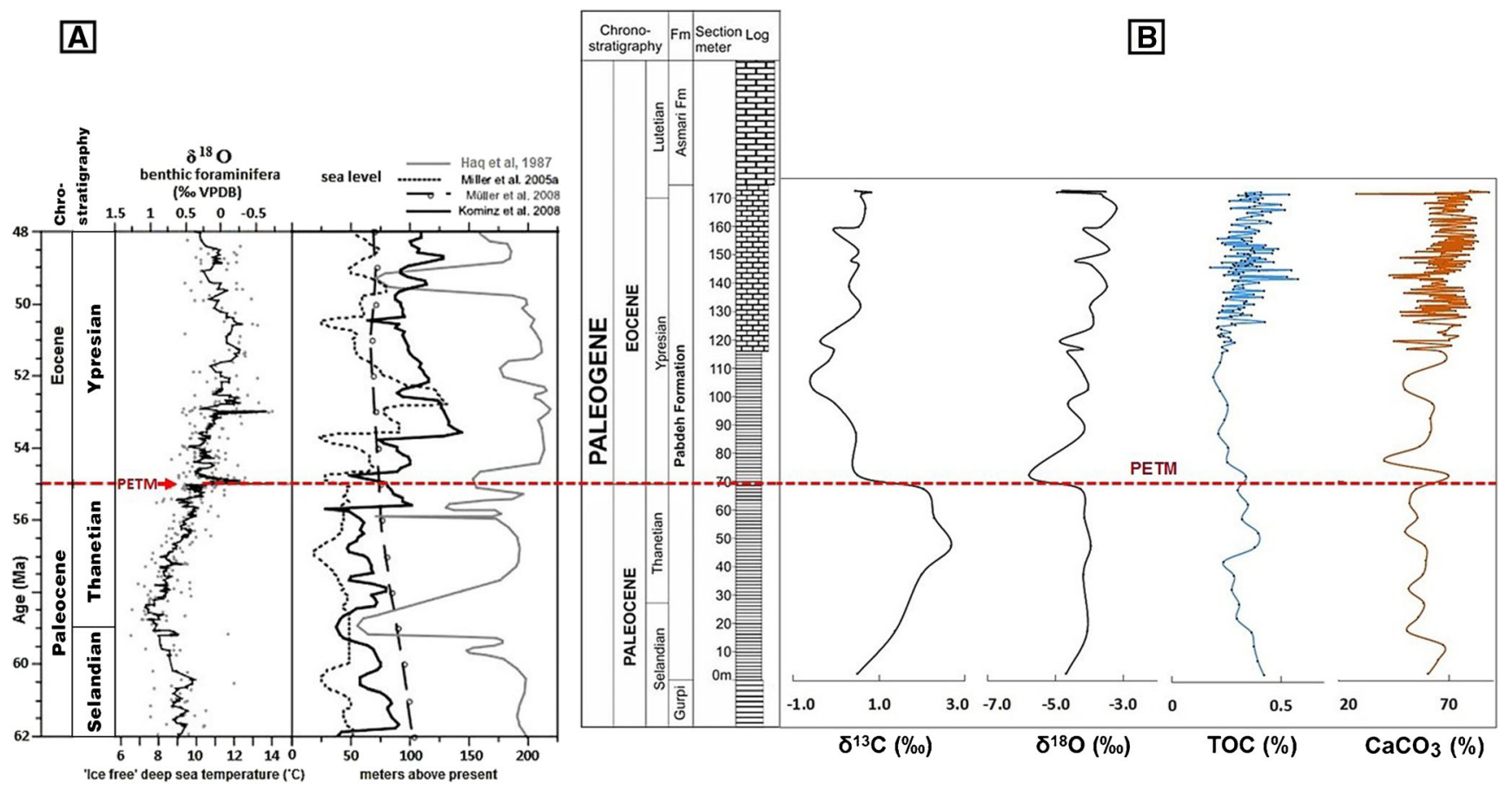

Fig. 9 A Comparison of deep-sea benthic foraminifer $\delta 180$ (Sluijs et al. 2008) as a sea temperature proxy and sea level records between 62 and $48 \mathrm{Ma}$. The temperature scale is based on the assumption that no continental ice was present. Sea level curves are from Haq et al. (1987), Miller et al. (2005), Kominz et al. (2008), and Muller et al. (2008). Muller et al.

rock weight (Nioti et al. 2013). The parallelism of carbonate and TOC maxima and minima indicates siliceous input and the opposite relationship marked by the dominance of carbonate flux (e.g., Khatun 2007). Therefore, we can say that there are high siliciclastic sediment supply in the lower parts of the Paryab section.

Various styles of deposition (low and high sediment supply and sediment production) form the bedding rhythms, related to changes in sedimentation rates between succeeding beds (Wagreich and Koukal 2019). Correlated TOC-CaCO 3 trends

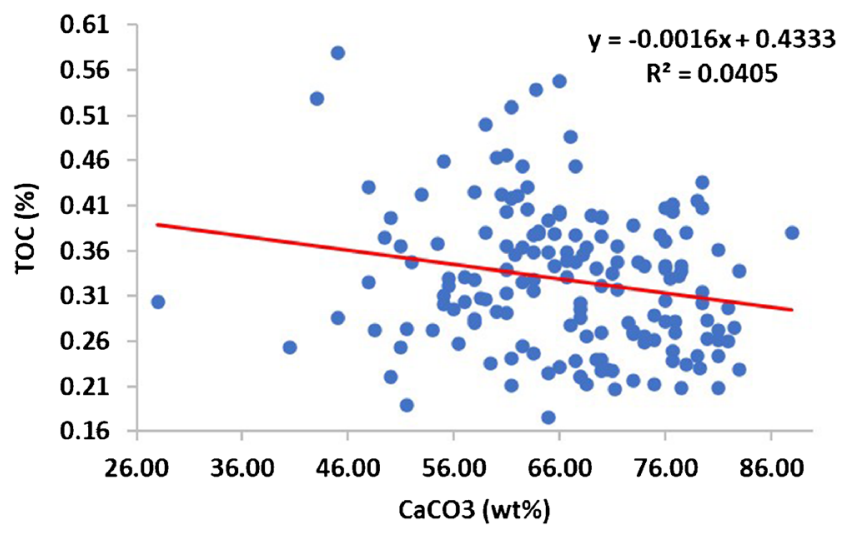

Fig. 10 TOC versus $\mathrm{CaCO}_{3}$ values of the Pabdeh Formation at the Paryab section. Slight negative correlation trend indicates carbonate flux variations (productivity cycles or plankton productivity-controlled carbonate deposition)
(2008) represent variations in ocean basin volume in meters of sea level assuming no ice sheets and a constant volume of ocean water. PETM, Paleocene-Eocene Thermal Maximum. B Stable carbon and oxygen isotope data of the Pabdeh Formation (VPDB) and total organic carbon and calcium carbonate content variations of the Pabdeh Formation

indicate that bedding rhythms have broad carbonate (limestone) maxima and small (shaly) minima that reflect variations in carbonate flux and thus are interpreted as productivity cycles (e.g., Khatun 2007; Elderbak and Leckie 2016). The plots of calcium carbonate weight percent and total organic carbon percent against the thickness of Pabdeh Formation show high siliciclastic supply in the lower part and low carbonate contents in the lower part of the section. Moreover, the upper marl-limestone rhythmic beds of the Paryab consist of intervals with higher oxygenation at the sediment surface that are expressed in a decreasing supply of organic matter (e.g., Khatun 2007). Variations of $\mathrm{Mn}, \mathrm{Ca}, \mathrm{Al}, \mathrm{Si}$, and Ti elements and $\mathrm{Mn} / \mathrm{Al}, \mathrm{Si} / \mathrm{Al}, \mathrm{Ti} / \mathrm{Al}$, and $\mathrm{Zr} / \mathrm{Al}$ normalized elemental ratios versus the thickness of the Pabdeh Formation are plotted in Fig. 12. As can be seen in Fig. 12, the negative correlation of the $\mathrm{Mn}$ and $\mathrm{Al}$ profile and the positive correlation of the $\mathrm{Mn}$ and $\mathrm{Ca}$ curves indicate that carbonates are the main source of $\mathrm{Mn}$; and the clastic influx of clay minerals is not significant in this respect, but rather dilutes Mn.

The trend of the Mn values does not correlate with the $\mathrm{Si}$, $\mathrm{Al}, \mathrm{Ti}$, and $\mathrm{Zr}$ content and $\mathrm{Si} / \mathrm{Al}, \mathrm{Ti} / \mathrm{Al}$, and $\mathrm{Zr} / \mathrm{Al}$ profiles. These opposite trends show that the detrital siliciclastic flux dilutes and thus diminishes $\mathrm{Mn}$ values. $\mathrm{Ni} / \mathrm{Co}$ ratio of the studied shales varies from 9.6 to 16.9 (average $=12.7$ ).

Geochemical parameters that are introduced by Jarvis et al. (2001), Jarvis et al. (2008), and Wagreich and Koukal (2019) 
Table 6 Some major (weight percent) and trace (parts per million) element concentrations for shale and limestone samples of Paryab section obtained by ICP-MS analysis

\begin{tabular}{llllllllll}
\hline Sample ID & $\begin{array}{l}\text { Py-1 } \\
\text { (shale) }\end{array}$ & $\begin{array}{l}\text { Py-16 } \\
\text { (shale) }\end{array}$ & $\begin{array}{l}\text { Py-22 } \\
\text { (shale) }\end{array}$ & $\begin{array}{l}\text { Py-33B } \\
\text { (shale) }\end{array}$ & $\begin{array}{l}\text { Py-49 } \\
\text { (limestone) }\end{array}$ & $\begin{array}{l}\text { Py-79 } \\
\text { (limestone) }\end{array}$ & $\begin{array}{l}\text { Py-105 } \\
\text { (limestone) }\end{array}$ & $\begin{array}{l}\text { Py-137 } \\
\text { (limestone) }\end{array}$ & $\begin{array}{l}\text { Py-171 } \\
\text { (limestone) }\end{array}$ \\
\hline $\mathrm{Al}_{2} \mathrm{O}_{3}$ & 5.23 & 6.19 & 5.33 & 2.82 & 4.50 & 5.92 & 5.63 & 3.34 & 2.30 \\
$\mathrm{P}_{2} \mathrm{O}_{5}$ & 0.23 & 0.13 & 0.13 & 0.1 & 0.08 & 0.08 & 0.33 & 0.19 & 0.14 \\
$\mathrm{~V}(\mathrm{ppm})$ & 75 & 65 & 78 & 39 & 60 & 93 & 337 & 233 & 38 \\
$\mathrm{Ni}(\mathrm{ppm})$ & 176.5 & 176.6 & 200.6 & 89.6 & 148.2 & 263.3 & 246.2 & 223.8 & 30.9 \\
$\mathrm{Co}(\mathrm{ppm})$ & 15.8 & 14.3 & 18.4 & 7.3 & 13.3 & 20.3 & 14.6 & 13.3 & 3.2 \\
$\mathrm{Cr}(\mathrm{ppm})$ & 438.5 & 496.9 & 993.8 & 292.31 & 526.16 & 935.39 & 876.93 & 716.16 & 131.54 \\
$\mathrm{Mo}(\mathrm{ppm})$ & $<0.1$ & $<0.1$ & $<0.1$ & $<0.1$ & $<0.1$ & 0.2 & 5 & 2.1 & 0.2 \\
$\mathrm{~V} / \mathrm{Cr}$ & 0.1710 & 0.1308 & 0.0785 & 0.1334 & 0.1140 & 0.0994 & 0.3842 & 0.3253 \\
$\mathrm{Ni} / \mathrm{Co}$ & 11.1708 & 12.3496 & 10.9022 & 12.2739 & 11.1428 & 12.97044 & 16.8630 & 16.8271 & 9.2888 \\
$\mathrm{~V} / \mathrm{V}+\mathrm{Ni}$ & 0.298 & 0.269 & 0.279 & 0.303 & 0.288 & 0.261 & 0.577 & 0.510 & 0.551 \\
\hline
\end{tabular}

are used to investigate further the pelagic record of sea level changes in the studied interval. Based on the $\mathrm{Mn}$ and $\mathrm{Ca}$ profile, the lower decreasing trend of $\mathrm{Mn}$ is coincident with the lowstand system tract (LST, Jarvis et al. 2001). With rising sea level (in the equivalent of the transgressive surface or TS), Mn sharply increases in the transgressive system tract (TST).

Maximum Mn values correlate with the theoretical maximum flooding surface (MFS). In the upper part of section, the Mn trend decreases again. This trend is coincident with the highstand system tract (HST, Jarvis et al. 2001). Siliciclastic input increases during regression (LST) (e.g., Wagreich and Koukal 2019). In the studied samples, Ti/Al and $\mathrm{Si} / \mathrm{Al}$ trends increase during the LST and decline during the TST. In the highstand stage, these ratios increase again slightly.

Global sea level changes (Haq et al. 1987; Miller et al. 2005; Kominz et al. 2008; Muller et al. 2008) show that the early Paleocene was associated with a long-term sea level decline and the late Paleocene to early Eocene sea level fluctuated between 50 and $220 \mathrm{~m}$ higher than at present. The middle Eocene was associated with a sea level drop (Sluijs
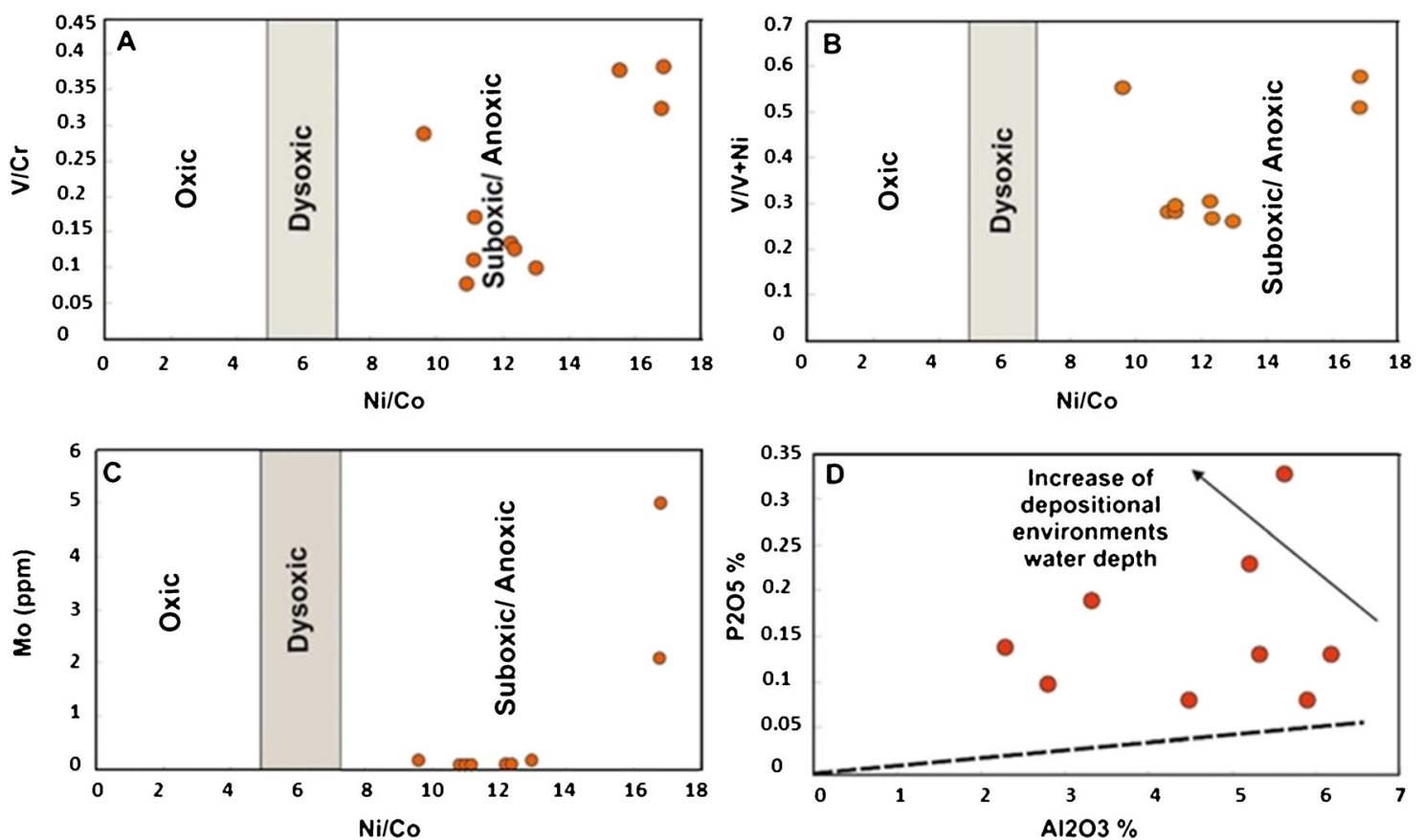

Fig. 11 Plots of $\mathbf{A}$ V/Cr against Ni/Co, B V/V + Ni versus Ni/Co, C Mo against Ni/Co, and D P2O5 versus $\mathrm{Al}_{2} \mathrm{O}_{3}$ of the studied samples in the Paryab section for paleoredox reconstructions 
Fig. 12 Chemostratigraphic profiles of $\mathrm{Si} / \mathrm{Al}, \mathrm{Ti} / \mathrm{Al}, \mathrm{Zr} / \mathrm{Al}, \mathrm{Ca}$, $\mathrm{Mn}$, and $\mathrm{Mn} / \mathrm{Al}$ and inferred sea level change for the Pabdeh Formation sequence

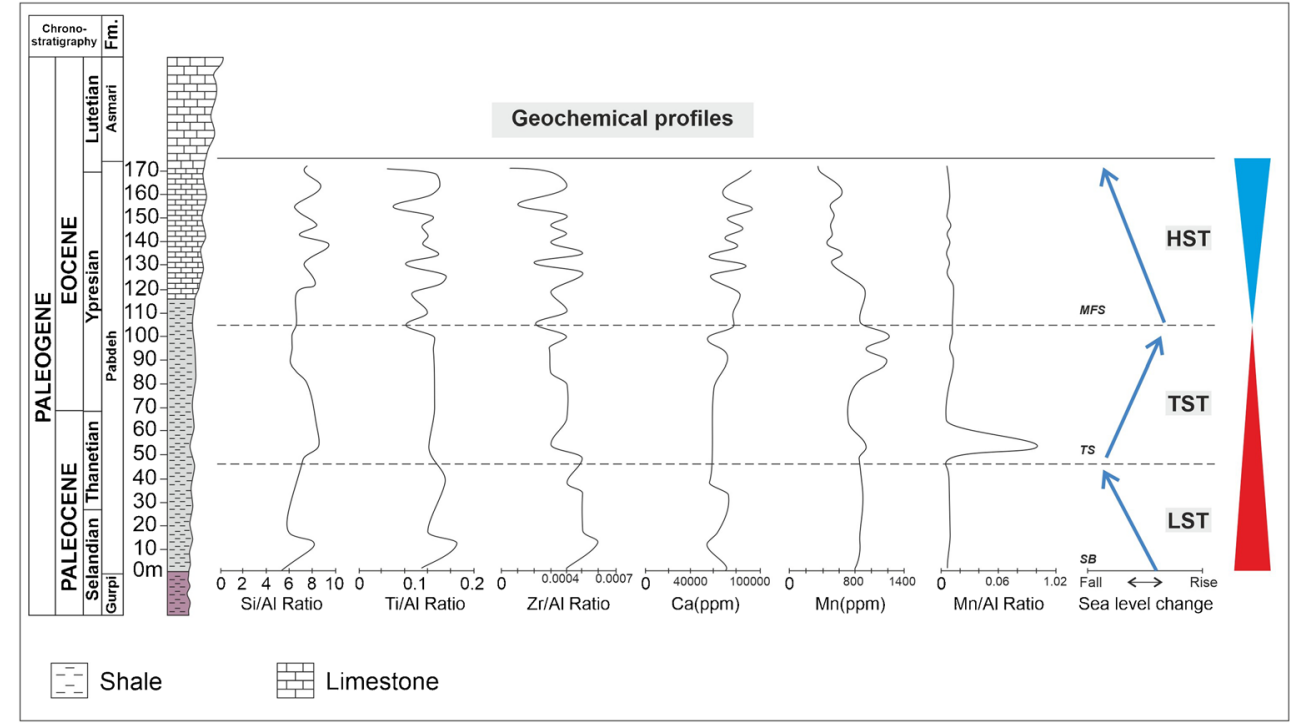

et al. 2008) (Fig. 9A). Sea level changes during the deposition of the Pabdeh Formation corresponded with these global sea level fluctuations. Periods with low Mn values are coincident with cooler climatic conditions and with sea level declines, while periods with high $\mathrm{Mn}$ content likely correspond to warmer climatic conditions and sea level increases due to glacio-eustatic factors or other processes (Sames et al. 2020).

\section{Paleoredox elemental indicators}

Many metallic elements are enriched in black shales: $\mathrm{Co}$, Mo, $\mathrm{Ni}, \mathrm{V}$, and $\mathrm{Cr}$ show particular affinities for organic-rich shales and mudstones (Potter et al. 2005). According to Dypvik (1984), Dill (1986), and Jones and Manning (1994), the values of $\mathrm{Ni} / \mathrm{Co}$ ratios are an indicator of paleoredox conditions and oxygen levels. Values of Ni/Co ratios below 5 indicate oxic environments, whereas values of this ratio above 5 are characteristic of dysoxic and suboxic/anoxic depositional environments (Jones and Manning 1994). These high Ni/Co ratios suggest that the deposition of these shales and limestones occurred under mainly suboxic to anoxic conditions. Contents of $\mathrm{P}_{2} \mathrm{O}_{5}$ and $\mathrm{Al}_{2} \mathrm{O}_{3}$ can also be used to delineate the depositional environments of marls and mudstones (Dhannoun and Al-Dlemi 2011).

\section{Depositional model}

Based on lithofacies, microfacies, and biofacies analyses, the studied shales and limestones were deposited in a deep marine environment (Azami et al. 2018) (Fig. 13). According to our data, these fine-grained sediments were deposited in suboxic to reducing conditions, which is in accordance with data published by Tabatabaei et al. (2012) from the Pabdeh Formation of the Bangestan anticline.

\section{Conclusions}

Grain size analyses, as well as mineralogical and geochemical-isotope studies, were used to understand the late

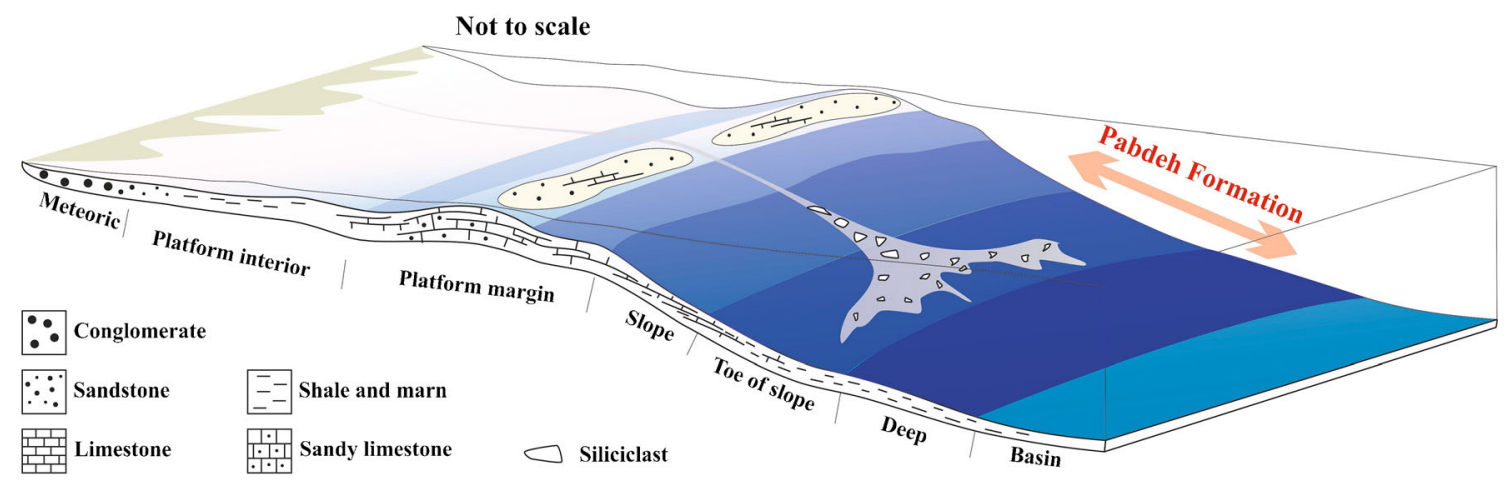

Fig. 13 Sedimentary environment model proposed for Pabdeh Formation strata in the studied section 
Paleocene to middle Eocene depositional processes and environments (especially the sea level change) in the Pabdeh Formation, Zagros basin, NW, Iran. Grain size analysis indicates mean values range from clay to coarse silt to very finegrained sand. Most of the samples are well sorted and are very coarsely skewed and extremely leptokurtic. These sediments are mostly clay to silt deposited in a deeper marine environment with only infrequent influence from weak bottom currents. The main mineral components of these pelagic sediments are carbonates and quartz. Predominant limestonemarl cycles are mainly driven by the carbonate productivity fluctuations of plankton. Paleoredox conditions of the studied fine-grained sediments based on elemental data are interpreted as suboxic to anoxic. Geochemical parameters such as manganese contents are used to aid in reconstructing major sea level changes. The lower decreasing trend of $\mathrm{Mn}$ is coincident with a major sea level lowstand. In the context of a rising sea level, Mn contents sharply increase in the transgressive systems tract. Maximum Mn values correlate with the hypothetical maximum flooding surface. In the upper part of the section, the Mn trend decreases again, indicating a major highstand. Negative correlation of $\mathrm{Mn}$ and $\mathrm{Al}$ and positive correlation of $\mathrm{Mn}$ and $\mathrm{CaCO}_{3}$ indicate that carbonates are the main source of $\mathrm{Mn}$, while clay mineral clastic influx is not a significant factor. The carbon isotope record of the studied Paryab section captures the sharp negative excursion in the PETM interval and serves as a proxy for how local sea levels corresponded to the major global sea level fluctuations during the late Paleocene to middle Eocene.

Acknowledgements Many thanks to Sabine Hruby-Nichtenberger and Maria Meszar (all University of Vienna) for sample preparation and lab analyses and to Kevin Kearny (University of Vienna) for English corrections.

Funding Open access funding provided by University of Vienna. For financial support, we would like to thank the UNESCO IGCP 609 Climate-environmental deteriorations during greenhouse phases: Causes and consequences of short-term Cretaceous sea-level changes, and the Austrian Academy of Sciences, International Research Programs.

\section{Declarations}

Conflict of interest The authors declare that they have no competing interests.

Open Access This article is licensed under a Creative Commons Attribution 4.0 International License, which permits use, sharing, adaptation, distribution and reproduction in any medium or format, as long as you give appropriate credit to the original author(s) and the source, provide a link to the Creative Commons licence, and indicate if changes were made. The images or other third party material in this article are included in the article's Creative Commons licence, unless indicated otherwise in a credit line to the material. If material is not included in the article's Creative Commons licence and your intended use is not permitted by statutory regulation or exceeds the permitted use, you will need to obtain permission directly from the copyright holder. To view a copy of this licence, visit http://creativecommons.org/licenses/by/4.0/.

\section{References}

Aiello IW, Kellett K (2006) Sedimentology of open-ocean biogenic sediments from ODP Leg 201, eastern equatorial Pacific (site 1225 and 1226). In: Jorgensen BB, D’ Hondt SL, Miller DJ (eds) Proc. ODP. Sci. Results 201:1-25

Angusamy N, Rajamanickam GV (2006) Depositional environment of sediments along the southern coast of Tamil Nadu, India. Oceanologia 48:87-102

Azami SHR, Wolfgring E, Wagreich M, Gharaie MHM (2018) Paleocene-Eocene calcareous nannofossil biostratigraphy and cyclostratigraphy from the Neo-Tethys, Pabdeh formation of the Zagros Basin (Iran). Stratigr Timescales 3:357-383

Baiyegunhi C, Liu K, Gwavava O (2017) Grain size statistics and depositional pattern of the Ecca groups and stones, Karoo Supergroup in the eastern Cape Province, South Africa. Open Geosci 9:554-576

Boggs SJ (2009) Petrology of sedimentary rocks, 2nd edn. Cambridge University Press, Cambridge

DeConto RM, Galeotti S, Pagani M, Tracy D, Schaefer K, Zhang T, Pollard D, Beerling DJ (2012) Past extreme warming events linked to massive carbon release from thawing permafrost. Nature 484:8791

Dhannoun H, Al-Dlemi A (2011) The relation between Li, V, P2O5, and $\mathrm{A} 12 \mathrm{O} 3$ contents in marls and mudstones as indicators of environment of deposition. Arab J Geosci 6:817-823

Dickens GR, Castillo MM, Walker JCG (1997) A blast of gas in the latest Paleocene: simulating first-order effects of massive dissociation of oceanic methane hydrate. Geology 25:259-262

Dill H (1986) Metallogenesis of early Paleozoic graptolite shales from the Graefenthal horst (northern Bavaria-Federal Republic of Germany). Econ Geol 81:889-903

Dunkley Jones T, Lunt DJ, Schmidt DN, Ridgwell A, Sluijs A, Valdes PJ, Maslin M (2013) Climate model and proxy data constraints on ocean warming across the Paleocene-Eocene thermal maximum. Earth Sci Rev 125:123-145

Dypvik H (1984) Geochemical compositions and depositional conditions of upper Jurassic and lower Cretaceous Yorkshire clays, England. Geol Mag 121:489-504

Elderbak K, Leckie RM (2016) Paleocirculation and foraminiferal assemblages of the Cenomanian-Turonian Bridge Creek limestone bedding couplets: productivity vs. dilution during OAE2. Cretac Res 60:52-77

Folk RL (1974) Petrology of sedimentary rocks. Hemphill Publishing Co., Austin $182 \mathrm{pp}$

Folk RL, Ward W (1957) Brazos River bar: a study in the significance of grain size parameters. J Sediment Petrol 41:1952-1984

Haq BU (2014) Cretaceous eustasy revisited. Glob Planet Chang 113:44 58

Haq BU, Hardenbol J, Vail PR (1987) Chronology of fluctuating sea levels since the Triassic. Science 235:1156-1167

Higgins JA, Schrag DP (2006) Beyond methane: towards a theory for the Paleocene-Eocene thermal maximum. Earth Planet Sci Lett 245: 523-537

Hönisch B, Ridgwell A, Schmidt D, Thomas E, Gibbs S, Sluijs A, Zeebe R, Kump L, Martindale R, Greene S, Kiessling W, Ries J, Zachos J, Royer D, Barker S, Marchitto T Jr, Moyer R, Pelejero C, Ziveri P, Foster G, Williams B (2012) The geological record of ocean acidification. Science 335:1058-1063 
Jarvis I, Murphy AM, Gale AS (2001) Geochemistry of pelagic and hemipelagic carbonates: criteria for identifying systems tracts and sea-level change. J Geol Soc Lond 158:685-696

Jarvis I, Mabrouk A, Moody RTJ, Murphy AM, Sandman RI (2008) Applications of carbon isotope and elemental $(\mathrm{Sr} / \mathrm{Ca}, \mathrm{Mn})$ chemostratigraphy to sequence analysis: sea-level change and the global correlation of pelagic carbonates. In: Salem MJ, El-Hawat AS (eds) Geology of East Libya. Earth Science Society of Libya, Tripoli $1: 369-396$

Jenkyns HC, Gale AS, Corfield RM (1994) Carbon and oxygen isotope stratigraphy of the English chalk and Italian Scalia and its palaeoclimatic significance. Geol Mag 131:1-34

Jones B, Manning DC (1994) Comparison of geochemical indices used for the interpretation of paleo-redox conditions in ancient mudstones. Chem Geol 111:111-129

Kennett JP, Stott LD (1991) Abrupt deep-sea warming, palaeoceanographic changes and benthic extinctions at the end of the Palaeocene. Nature 353:225-229

Kent DV, Cramer BS, Lanci L, Wang D, Wright JD, Van der Voo R (2003) A case for a comet impact trigger for the Paleocene/Eocene thermal maximum and carbon isotope excursion. Earth Planet Sci Lett 211:13-26

Khatun M (2007) Interpretation as three component system. Chapter 7

Kidder DL, Worsley TR (2010) Phanerozoic large igneous provinces (LIPs), HEATT (Haline Euxinic acidic thermal transgression) episodes, and mass extinctions. Palaeogeogr Palaeoclimatol Palaeoecol 295:162-191

Kominz MA, Browning JV, Miller KG, Sugarman PJ, Mizintseva S, Scotese CR (2008) Late Cretaceous to Miocene sea-level estimates from the New Jersey and Delaware coastal plain coreholes: an error analysis. Basin Res 20:211-226

Köster E (1964) Granulometrische und morphometrische Messmethoden an Mineralkörnern. Steinen und sonstigen Stoffen, Stuttgart 336 p

Krenmayr HG (1996) Hemiplagic and turbidite mudstone facies associations in the upper Cretaceous Gosau group of the northern calcareous Alps (Austria). Sediment Geol 101:149-172

Mason B, Moore CB (1982) Principles of geochemistry, 4th edn. Wiley, New York $344 \mathrm{p}$

McInerney FA, Wing SL (2011) The Paleocene-Eocene thermal maximum: a perturbation of carbon cycle, climate, and biosphere with implications for the future. Annu Rev Earth Planet Sci 39:489-516

Miller KG, Wright JD, Browning JV (2005) Visions of ice sheets in a greenhouse world. Mar Geol 217:215-231

Moore DM, Reynolds RC Jr (1997) X-Ray Diffraction and the Identification and Analysis of Clay Minerals, 2nd ed. xviii +378 , pp. Oxford, New York: Oxford University Press

Muller RD, Sdrolias M, Gaina C, Steinberger B, Heine C (2008) Longterm sea-level fluctuations driven by ocean basin dynamics. Science 319:1357-1362

Nesbitt HW, Young GM (1982) Early Proterozoic climates and plate motions inferred from major element chemistry of lutites. Nature 299:715-717

Nioti D, Maravelis A, Tserolas P, Zelilidis A (2013) TOC and CaCO3 content in Oligocene shelf deposits on Lemnos Island and their relation with depositional conditions. Bull Geol Soc Greece 47: 852-861

Olde K, Jarvis I, Ulicny D, Pearce MA, Trabucho-alexander J, Cech S, Grock DR, Laurin J, Svabenicka L, Tocher BA (2015) Geochemical and palynological sea-level proxies in hemiplegic sediments: a critical assessment from the upper Cretaceous of the Czech Republic. Paleogeogr Paleoclimatol Paleoecol 435:222-243

Passega R (1964) Grain size representation by C-M pattern as a geological tool. J Sediment Petrol 34:830-847

Potter PE, Matnard JB, Depetris PJ (2005) Mud and mudstones: introduction and overview. Springer- Verlag, Berlin, 297 p

Rajesh E, Anbarasu K, Rajamanickam GV (2007) Grain size distribution of silica sand in and around Marakkanam coast of Tamil Nadu. J Geol Soc India 69:1361-1368

Ricken W (1993) Sedimentation as a three-component system: organic carbon, carbonate, noncarbonate. Lect Notes Earth Sci:207 p

Ricken W (1996) Bedding rhythms and cyclic sequences as documented in organic carbon-carbonate patterns, upper Cretaceous, Western Interior, U.S. Sediment Geol 102:131-154

Roser BP, Korsch RJ (1988) Provenance signatures of sandstonemudstone suites determined using discriminant function analysis of major-element data. Chem Geol 67:119-139

Sames B, Wagreich M, Conrad CP, Iqbal S (2020) Aquifer-eustasy as the main driver of short-term sea-level fluctuations during Cretaceous hothouse climate phases. Geol Soc Spec Publ 498:9-38

Sluijs A, Brinkhuis H, Crouch EM, John CM, Handley L, Munsterman D, Bohaty SM, Zachos JC, Reichart G, Schouten S, Pancost RD, Sinninghe Damste JS, Welters NLD, Lotter AF, Dickens GR (2008) Eustatic variations during the Paleocene-Eocene greenhouse world. Paleoceanography 23:1-18

Spötl C, Vennemann T (2003) Continuous-flow isotope ratio mass spectrometric analysis of carbonate minerals. Rapid Commun Mass Spectrom 17:1004-1006

Svensen H, Planke S, Malthe-Sorenssen A, Jamtveit B, Myklebust R, Eidem TR, Rey SS (2004) Release of methane from a volcanic basin as a mechanism for initial Eocene global warming. Nature 429:542545

Tabatabaei H, Motamed A, Soleimani B, Kamali MR (2012) Geochemistry of Gurpi-Pabdeh-Asmari formations and its implication on chemical variation during deposition of Pabdeh formation, Zagros Basin. Himal Geol 33:126-138

Thomas E, Shackleton NJ (1996) The Paleocene-Eocene foraminifera extinction and stable isotope anomalies. In: Knox, R.W.O.B., Corfield, R.M., Dunay, R.E. (Eds.), Correlation of the early Paleogene in Northwest Europe. Geol Soc Spec Publ 101:401-441

Udden JA (1914) Mechanical composition of clastic sediments. Geol Soc Am Bull 25:655-744

Wagreich M, Koukal V (2019) The pelagic archive of short-term sealevel change in the cretaceous: a review of proxies linked to orbital forcing. Geol Soc Lond Spec Publ 498:39-56

Wentworth CK (1922) Method of computing mechanical composition types in sediments. Geol Soc Am Bull 40:771-790

Zachos JC, Pagani M, Sloan L, Thomas E, Billups K (2001) Trends, rhythms, and aberrations in global climate $65 \mathrm{ma}$ to present. Science 292:686-693

Zachos JC, Dickens GR, Zeebe RE (2008) An early Cenozoic perspective on greenhouse warming and carbon-cycle dynamics. Nature 451: $279-283$

Zeebe RE, Dickens GR, Ridgwell A, Sluijs A, Thomas E (2014) Onset of carbon isotope excursion at the Paleocene-Eocene thermal maximum took millennia, not 13 years (comment). Proc Natl Acad Sci USA 111:1062-1063 